\title{
Distanční výuka na druhou
}

\author{
Jana Krátká, Lenka Zemanová \\ Univerzita Karlova, Pedagogická fakulta, Katedra preprimární a primární pedagogiky
}

\begin{abstract}
Abstrakt: Cílem příspěvku je poskytnout reflexi změn předmětu učitelské praktikum II vyučovaného na Pedagogické fakultě Univerzity Karlovy nastalých v souvislosti s pandemií v březnu 2020, která zapříčinila uzavření škol na všech stupních. V první části text popisuje podmínky kurzu platné před počátkem karantény. Druhá část příspěvku uvádí, k jakým změnám později muselo dojít, aby studentům bylo umožněno úspěšné zakončení předmětu ve standardní době studia. Třetí část je věnována popisu vzdělávacích nástrojů, které v této době využívají fakultní učitelé spolu se studenty v praxi při vyučování na prvním stupni běžných základních škol na území hlavního města Prahy. Ukázalo se, že systém funguje a mohl by být inspirací i do budoucna. Z uvedeného vyplývá, že $\mathrm{v}$ tomto případě se podařilo reagovat na aktuální potřeby žáků a studentů a byla zajištěna smysluplná a funkční distanční výuka jak pro žáky prvního stupně, tak pro vysokoškolské studenty.
\end{abstract}

Klíčová slova: distanční výuka, covid-19, učitelské praktikum II, vysokoškolští studenti, žáci prvního stupně základní školy

$\mathrm{V}$ době uzavření škol $\mathrm{v}$ době pandemie koronavirového onemocnění covid-19 v březnu 2020 byli učitelé všech stupňů škol postaveni před otázku, jak vyučovat na dálku. Museli přemýšlet nad otázkami, jak navázat komunikaci se svými žáky a př́ípadně s jejich rodiči, jaké materiály využívat, jakou formou vyučovat. Museli se zamýšlet nad dvěma základními tématy: CO vyučovat a JAK vyučovat, protože kromě formy bylo nutné promyslet také obsah. Nebylo možné vyučovat dál stejně jako dosud. Zamýšleli se nad tím jak učitelé základních a středních škol, tak také vysokoškolští pedagogové. Mezi ně patří také autorky tohoto textu, které v příspěvku poskytnou reflexi z výuky učitelského praktika II vyučovaného na Katedře preprimární a primární pedagogiky Pedagogické fakulty Univerzity Karlovy.

\section{Charakteristika předmětu učitelské praktikum II.}

Jedním z předmětů, které pro studenty oboru učitelství pro první stupeň ZŠ předepisuje Pedagogická fakulta Univerzity Karlovy v Praze, je učitelské praktikum II. Základním obsahem učitelského praktika II je pravidelné vyučování v jedné třídě, plánování, realizace a reflexe vlastní pedagogické činnosti s žáky. Vyučování charakterizují jak jednotlivé činnosti, tak i celodenní 
tematické vyučování. V akademickém roce 2019/2020 si předmět zapsalo 76 studentů, ti byli vzhledem k vysokému počtu rozděleni do sedmi paralelních skupin. Každou z paralelních skupin vedl jeden či dva vyučující. Kurz si povinně zapisují studenti 2 . ročníku, prerekvizitou předmětu je v zimním semestru učitelské praktikum I. Cílem této pedagogické praxe je vést studenty k hlubšímu poznání konkrétní školy, tř́ídy, učitele, a především žáků. Důraz je kladen na rozvíjení dovedností studentů v oblasti komunikace s žáky, vytváření podnětného prostředí pro výuku a budování sociálního klimatu ve třídě. Předměty učitelského praktika probíhají na prvním stupni běžných základních škol na území hlavního města Prahy.

V rámci jednotlivých paralelních skupin jsou studenti většinou po třech přiděleni do konkrétních tříd základních škol. Po dobu celého semestru studenti jednou týdně ve třídách hospitují a pod dohledem zkušeného pedagoga, fakultního učitele, také vyučují. Přítomen je taktéž vyučující kurzu, který nejen dokumentuje docházku (povolené jsou celkem dvě absence), ale také hodnotí pokroky studentů a spolu s fakultním učitelem provádí rozbor zhlédnutých hodin a poskytuje zpětnou vazbu $\mathrm{k}$ hodinám vyučovaným studentem. Při první návštěvě školy se studenti především seznamují s prostředím, učitelem a žáky, domlouvají si s fakultním učitelem další postup a plánují činnosti pro nadcházející týdny.

Celkem v rámci semestru probíhá minimálně deset návštěv, vždy po dobu tří vyučovacích hodin, přičemž třetí vyučovací hodina je vedena právě studentem. Na závěrečném setkání ve třídě studenti realizují projektové vyučování nebo integrovanou tematickou výuku. Během semestru studenti průběžně vedou dokumentaci v prostředí Moodle, které je využíváno pro elektronickou výuku na jednotlivých fakultách Univerzity Karlovy. Sem vkládají záznamy z reflexí a pozorování vyučovacích hodin a přípravy vlastních učitelských pokusů před výukou. Tyto př́pravy ještě před samotnou realizací projdou kontrolou nejen fakultního učitele, $v$ rámci jehož třídy probíhá hospitace, ale i kontrolou vyučujícího kurzu. Celkem je požadováno minimálně sedm takových př́prav s následnou reflexí. Příprava musí obsahovat co nejkonkrétněji formulovaný cíl a zvolené aktivity by měly k tomuto cíli směřovat. Studenti by měli v přípravě vždy zařadit aktivitu, která poskytne jim i žákům co nejkonkrétnější zpětnou vazbu $\mathrm{k}$ tomu, zda a do jaké míry bylo cíle dosaženo. Součástí kurzu je taktéž esej na téma Stávám se učitelem či Jaký jsem učitel. Závěrečnou částí je vyplnění souboru profesních kvalit studenta v rámci pedagogické praxe. Jedná se o sebehodnocení a zároveň hodnocení studenta fakultním učitelem. 
Po dopoledním bloku učitelského praktika II následuje odpolední blok předmětu didaktika prvního stupně ZŠ II. Jedná se o seminář, který volně navazuje na pedagogickou praxi. Od studentů se vyžaduje, aby to, co se v semináŕích naučí, dokázali aplikovat právě v rámci pedagogické činnosti. Seminář didaktiky prvního stupně ZŠ je taktéž rozdělen do paralelních skupin. Cílem je vést studenty k používání didaktických znalostí pro rozvoj profesních kompetencí a zpracovávání didaktických problémů. Předmět navazuje na témata probíraná v didaktice prvního stupně ZŠ I a na praktické zkušenosti z plánování, realizace a reflexe vyučovacích činností v učitelském praktiku II.

\section{Změny v době karantény}

Realizace předmětu učitelské praktikum II v této podobě najednou nebyla ve druhé polovině března 2020 po uzavření škol možná. A tak se studenti, kteří již nyní byli v dvojroli student/učitel na praxi, ocitli ve stejné roli ve zcela novém kontextu, ve výuce na dálku. Aby bylo možné $v$ akademickém roce pokračovat, bylo nutné předmět uzpůsobit situaci a převést jej do distanční podoby. Především u předmětů z oblasti praxe je tento převod obzvláště náročný. Zásluhou pedagogických i akademických pracovníků se však ukázalo, že zdánlivě nerealizovatelnou praxi na dálku lze uskutečnit.

V prvním týdnu po uzavření veškerých školských i mimoškolních zařízení byla zcela zásadní komunikace všech vyučujících jednotlivých paralelních skupin, kteří museli ustanovit jednotné podmínky pro pokračování kurzu. Následovala fáze, $v$ níž bylo nutné oslovit fakultní učitele a ujistit se, zda jsou ochotni studenty vést i v takovéto situaci, a to za předpokladu, že studenti budou nápomocni při vytváření distanční podpory pro žáky. Všichni souhlasili. I přesto, že každý fakultní učitel postupoval podle svých zkušeností a dovedností trochu jinak, studenti se velice rychle přizpůsobili a začali spolupracovat. Již po několika týdnech bylo jasné, že do konce školního roku nebude studentům umožněn vstup do škol, a tím ani přímá pedagogická činnost. Podmínky kurzu se upravily tak, aby studentům bylo umožněno splnit předmět ve standardní době studia. $V$ praxi to znamená, že studenti plnili pokyny fakultních učitelů, vytvářeli prezentace na zadaná témata, týdenní plány či pracovní listy. Ty odevzdávali do prostředí Moodle a vyučující kurzu je průběžně hodnotil a poskytoval zpětnou vazbu. 


\subsection{Popis průběhu praxe na dálku v jedné z paralelních skupin}

$V$ této části se zaměříme na popis průběhu činností $v$ jedné $\mathrm{z}$ paralelních skupin, v níž je zapsáno devět studentů, kteří svou praxi původně plnili v 1., 3 . a 4. třídě prvního stupně ZŠ, tedy pod vedením tř́i učitelů na jedné z pražských základních škol. Studenti byli vyzváni, aby oslovili svého fakultního učitele (nejlépe zástupce za skupinu) a zmapovali jeho systém distanční výuky žáků. $K$ tomuto systému měli za úkol napsat krátkou popisnou zpětnou vazbu o tom, co a proč na tomto systému oceňují. V týdnu od 16 . března navrhli studenti učiteli pomoc $\mathrm{v}$ rámci přípravy distančního vyučování. Zjištovali, zda by bylo možné, aby byli do distančního vzdělávání podle konkrétní situace zapojeni. $\mathrm{V}$ takovém případě pak podíl na výuce nahrazoval přímou pedagogickou činnost. $\mathrm{V}$ opačném případě by byla studentovi nabídnuta jiná alternativa, takový případ však nenastal.

V rámci dalšího úkolu byla studentům poskytnuta ukázka distanční formy vzdělávání, kterou v reakci na vzniklou situaci uzavření škol vytvořil jeden $\mathrm{z}$ fakultních učitelů pro své žáky z 1 . třídy. Úkolem bylo pečlivě prostudovat přiložené materiály a vypracovat reflexi. Každý student v Moodle zakládal ve fóru vlákno se svým jménem a dokladoval každý týden od 24. března do 12 . května 2020 práci v rozsahu minimálně tří hodin týdně a její výsledky. Studenti vkládali konkrétní doklady, tedy texty pracovních listů, odkazy na vytvořené e-materiály atd. $V$ př́ípadě, že student neplnil požadované instrukce ve stanoveném čase, byla počítána absence na tomto předmětu. Studenti tedy v tomto konkrétním př́padě i nadále spolupracovali s přidělenými fakultními učiteli. Původní úkoly - esej na téma Jaký jsem učitel či Stávám se učitelem a odevzdání souboru studentových prací v rámci sebehodnocení - zůstávají.

Ze zpětné vazby, kterou vyučujícím učitelského praktika II poskytli studenti, vyplývá, že na fakultních školách, se kterými Univerzita Karlova spolupracuje, byly děti i nadále vzdělávány svými třídními učiteli. Výuka probíhala online, zpravidla alespoň dvakrát týdně se zaměřením na český jazyk, matematiku, vlastivědu a prrírodovědu, příp. prvouku. Děti byly v rámci třídy rozděleny do kmenových skupin. Učitel tedy vyučoval každý den, přičemž jednotlivé skupiny se strrídaly. Práce tak byla podle slov učitelů efektivnější a byl umožněn individuální př́istup. Jednou týdně učitelé rodičům zasílali týdenní plán a na dané dny rozepisovali podrobné denní plány. Nastávaly i situace, kdy děti plnily nejen povinné úkoly, ale vyžadovaly i dobrovolné úkoly. Pro účely distančního vzdělávání školy vytvořily edukační platformy, kam žáci splněné 
úkoly zasílali. K vkládání úkolů byl využíván také Google Disk. Vzhledem k časovému období studenti sestavovali tematicky založené př́ípravy na téma Velikonoce, Den vítězství nebo Den matek. Případné poznámky a požadavky žáků předával studentům fakultní učitel. Jako online i offline výukové materiály byly využívány grammar.in, matika.in, učebnice a pracovní sešity.

\subsection{Způsoby komunikace}

Studenti s fakultními učiteli komunikovali převážně e-mailem a telefonicky nebo prostřednictvím Skype, případně využívali Google Meet či Google Classroom. Studenti se podíleli na př́ípravě výukových materiálů, tvořili denní plány, úlohy, prezentace, pracovní listy. Čerpali ze zdrojů, které poskytoval učitel (scan či opis učebnice nebo pracovního sešitu), popřípadě vytvářeli vlastní materiály (pracovní listy, křížovky, celotýdenní projekt). S žáky se studenti „,setkávali“ každý týden v online hodinách, v některých případech měli možnost se zapojit i do ranního kruhu. Zároveň jim také učitelé umožňovali tyto online vyučovací hodiny vést, přípravu studenti s učiteli předem konzultovali. Po online hodině probíhala reflexe s učitelem, a to přímo ve videohovoru nebo v rámci online Google souboru, skrze vzájemné reakce. Z počátku karantény byla potřeba tvorby distanční podpory intenzivnější, postupně se s rozvolňováním a možností nástupu dětí do škol od 25 . května snižovala.

\subsection{Hodnocení studentů}

Studentům dávali zpětnou vazbu jednak jejich fakultní učitelé přímo v souvislosti s výukou, jak bylo uvedeno výše, jednak jejich vyučující z fakulty. Ti reagovali v prostředí Moodle na úkoly, které tam studenti umistovali. Jejich forma hodnocení studentů byla tedy stejná jako v době mimo karanténu. Pro tyto vyučující to ale také byla nová zkušenost v tom smyslu, že se zamýšleli nad jinými výstupy svých studentů než obvykle. Zůstal sice esej i sebehodnocení studentů, ale průběh výuky, na níž se studenti podíleli, byl odlišný. Předmět byl zakončen udělením zápočtu.

\section{Závěr}

Studentům bylo umožněno nahlédnout do vzdělávacího systému i z jiného pohledu, dosud neprozkoumaného. Jednalo se o první zkušenost s takovýmto způsobem vzdělávání - pro studenty i pro učitele, a to jak pro fakultní učitele na základních školách, tak pro vyučující na pedagogické fakultě. Na 
základě zkušeností uvedených studenty oboru učitelství prvního stupně ZŠ lze konstatovat, že samotní studenti distanční vzdělávání vnímají jako náročnější pro učitele, a to především časově. Také není snadné odhadnout rozsah zadaných úkolů a zároveň motivovat děti k práci, přemýšlet o estetické stránce zadávaných úkolů (prezentace, pracovní listy), tedy jak žáka zaujmout. Jednoznačně se jedná o velice zajímavou a př́nosnou zkušenost pro všechny zúčastněné. Učitelé se shodují, že by některé prvky z distanční výuky rádi využívali i v budoucnu, např. sdílení výukových materiálů na Google Disku. Využily by je zejména děti, které $\mathrm{z}$ důvodu nemoci nemohly být ve škole, ale zároveň by byly $\mathrm{k}$ dispozici všem žákům k opakování a procvičování. Vyučující na pedagogické fakultě si díky této mimořádné situaci ověřili, že předmět, jehož cílem je poskytnout studentům přímou praktickou zkušenost s výukou na prvním stupni základní školy, je realizovatelný i v distanční formě. Pro ně samotné byla tato situace nejméně odlišná od běžného způsobu výuky předmětu učitelské praktikum II., protože hodnotili výstupy studentů v prostředí Moodle stejně jako obvykle, pouze ve větším rozsahu. Studenty tento způsob výuky nijak neomezil ve studiu a měli možnost předmět zakončit a získat zápočet ve standardní době studia.

\section{Autoři}

Mgr. Jana Krátká, Univerzita Karlova, Pedagogická fakulta, Katedra preprimární a primární pedagogiky, Magdalény Rettigové 4, 11639 Praha 1, e-mail: jana.kratka@pedf.cuni.cz

Mgr. et Mgr. Bc. Lenka Zemanová, Univerzita Karlova, Pedagogická fakulta, Katedra preprimární a primární pedagogiky, Magdalény Rettigové 4, 11639 Praha 1, e-mail: lenka.zemanova@pedf.cuni.cz 